\title{
DA GUD BLEV TIL EN LILLE GRØN MAND FRA RUMMET
}

\author{
Et eksempel på mytologisk kontinuitet og inversion
}

\author{
Af Mikael Rothstein
}

Religiøse innovationer er sjældent - måske aldrig - virkelige nyskabelser. Som regel er de nye trossystemer blot reproduktioner eller reformuleringer af allerede eksisterende forestillinger. For en umiddelbar betragtning kan det ganske vist synes, som om en ny religion eller et nyt trossystem manifesterer hidtil usete ideer, men ved nærmere studier vil det typisk vise sig, at der intet morfologisk nyt er ved det nye. Et karakteristisk udtryk for dette forhold er de nye religioners udprægede orientering mod det synkretistiske og eklektiske. Man etablerer nye synteser på grundlag af allerede eksisterende materiale, eller man viderefører velkendte religiøse strukturer i nye formuleringer. Af og til sker dette i harmoni med traditionens grundsætninger, mens der andre gange er tale om radikale omskrivninger af det mytologiske materiale. Naturligvis er der undtagelser fra dette mønster, men de er få og langt mindre signifikante end den kontinuitet, som afspejles i de nye religioners reviderede videreførelse af eksisterende traditioner.

I det følgende skal jeg beskrive en religion, en af tidens mange UFO-kulter, som unægtelig forekommer særegen. Som det vil fremgå, drager den imidlertid på velkendte religiøse forestillinger og strukturer, hvorfor den udgør et glimrende eksempel på religiøs innovation forstået som kreativ reinterpretation. Min hensigt er at fremlægge et eksempel p̊̊, hvordan nye religioner kan udvikles på grundlag af gamle, og især at vise, hvordan nye teologier kan udvikles i harmoni med den moderne verdens fordringer.

Udforskningen af UFO-kulter intensiveres i disse år. Det er især folklorister, som har emnet på programmet, og det er naturligvis oplagt, fordi UFO-fænomenet på mange måder må forstås som en del af den moderne folklore. Flere religionssociologer har imidlertid også beskæfti- 


\section{Da Gud blev til en lille grøn mand}

get sig med fænomenet. ${ }^{1}$ Den akademiske interesse må selvfølgelig ikke forveksles med den interesse for UFO'er, som trives i mangfoldige interessegrupper uden religiøse motiver. UFO-fænomenet kan fragmentarisk identificeres tilbage $\mathrm{i}$ historien, men den aktuelle interesse startede $\mathrm{i}$ 1947, da en amerikansk pilot angiveligt så en eskadrille flyvende tallerkener. Sidenhen har folk over hele verden (i flere boom) rapporteret om UFO'er og ufonauter af forskellig type. UFO'er iagttages angiveligt hver dag af mennesker uden religiøse forudsætninger for at se dem (et af de temaer folkloristerne ofte studerer), og derfor er interessen for sagen stor. Blandt de ikke-konfessionelle ufologer er meningerne spredte. Mange antager, at der er tale om rumskibe fra fremmede kloder eller andre dimensioner, mens andre er mere skeptiske og anser de flyvende tallerkener - hvis de da er der - for at være hidtil ukendte naturfænomener. Den religiøse beskæftigelse med UFO'erne forbindes ofte til teosofiens forestilling om åndelige mestre, hvis oprindelse typisk henlægges til Venus. Det bemærkelsesværdige er således, at fænomenet UFO'er optræder i forskellige kulturelle lag, og at den religiøse fortolkning af fænomenet (hvad det så end måtte være) er én fortolkningsvinkel blandt flere. I denne artikel forsøger jeg at nærme mig betydningsdannelsen og meningsdannelsen i en enkelt UFO-kult.

\section{Claude Vorlihon (Raël) og Elohim}

Den 13. december 1973 havde en ung franskmand, racerkøreren og journalisten Claude Vorlihon (f. 1946) en skelsættende oplevelse. Under en klatretur i det indre af en udslukt vulkan ved Clermont-Ferrand i det centrale Frankrig blev han konfronteret med en stærkt lysende, flad og afrundet genstand på størrelse med en stor bil, som lydløst steg ned fra himlen, gennem krateråbningen til den forundrede Vorlihon. Det var en såkaldt flyvende tallerken, et »uidentificeret flyvende objekt« (UFO). Identifikationen skulle imidlertid følge hurtigt efter. Ud af det med rødt og hvidt lys pulserende fartøj trådte en skikkelse på ca. 1,20 meter. Skikkelsen var, fortæller Vorlihon, ikke et barn, men et voksent menneskeligt væsen. Skikkelsen var klædt i grøn heldragt, men havde bart hoved. Hans sorte hår nåede skuldrene, hans øjne var mandelformede, og han havde et lille elegant fipskæg. Hans hud var lys grønlig, nærmest lidt 
gusten efter Vorlihons beskrivelse at dømme. Den lille mand kom fra en anden planet, hvilket han fortalte Vorlihon på formfuldendt fransk. Den fremmede fortalte, at han havde været på jorden mange gange før, og at han mestrede alle jordens sprog.

Den ikke-jordiske humanoid præsenterede sig som Eloha, en repræsentant for den race - Elohim - som skabte menneskeheden, eller rettere den jordiske menneskehed. Da Vorlihon spurgte, om der var langt til Elohas planet, svarede han, at der var meget langt! Han fortalte, at Elohim levede på en planet magen til jorden, at de er mennesker som os, at de kan rejse gennem universet med tankens hastighed, og at de kommer hertil for at overvåge menneskehedens udvikling og værne om os.

Den lille humanoid forklarede Vorlihon, at han (Vorlihon) var blevet styret telepatisk til vulkanen, og at Elohim havde holdt øje med ham hele hans liv. Hans rolle som Elohims profet - under navnet Raël - i "Apokalypsens Tidsalder « blev nu åbenbaret for ham, og han fik forklaret, at man havde valgt Frankrig som udgangspunkt for missionen, fordi demokratiet fødtes her. Vorlihon fik også forklaret, at han selv, som søn af en jødisk far og en katolsk mor, var den perfekte mediator mellem jødedom og kristendom, hvilket angiveligt ville være en fordel for hans mission. ${ }^{2}$

\section{The International Raëlian Movement}

Dermed var grunden lagt til en af de bedst konsoliderede UFO-kulter, som i dag virker over det meste af verden. I en orienteringsskrivelse fra 1992 hævdes det, at bevægelsen tæller over 50.000 medlemmer, og at væksten i medlemmernes antal er $30 \%$ om året. Tallene kan umuligt være rigtige; her, som i de fleste andre nye religioner, manipuleres der oplagt med medlemstallet. ${ }^{3}$ Til gengæld er det veldokumenteret, at The International Raëlian Movement med hovedsæde i Schweitz virker i over 40 lande i alle verdensdele. ${ }^{4}$ Med Raël som det karismatiske centrum (med status af profet og Messias), virker bevægelsen for at oplyse enhver om Elohims budskaber, hvilket sker gennem foredrag og mangfoldige publikationer, hovedsagelig på fransk og engelsk. I en folder opsummeres Elohims budskab således: 


\section{Da Gud blev til en lille grøn mand}

On the 13th December 1973, a journalist named Raël was contacted by a UFO. The occupant told him: "We created humanity. You mistook us for Gods. We were the ones who started all the religions on earth. Now that humanity is capable of understanding this, we would like you to build us an Embassy«.

The occupant explained how, just as we are now synthesising life in our laboratories using DNA, it was they who created all life on earth including »Man in their image a long time ago. This was a work of love.

Traces of this epic masterpiece can be found not only in the Bible, but in the ancient texts of many cultures, as can their symbol of infinity. ${ }^{5}$

However, in the original Bible, it does not say "God*, but »Elohim «, which in ancient Hebrew means »Those who come from the sky« and is a plural of »Eloha ${ }^{6}{ }^{6}$

It was they who sent all the PROPHETS such as Moses, Jesus and Mohammed to progressively educate humanity with a message adapted to the level of understanding of each age.

Now that we ourselves are synthesising DNA and so are scientifically advanced enough to understand our origins, they wish us to prepare an EMBASSY for them where they can meet with us, our governments and the media - without favouring one country above another. ${ }^{7}$

På denne baggrund formulerer man sin hensigtserklæring:

The Raëlian Movement exists; to inform everyone about these messages without trying to convince; to build an Embassy for the Elohim in internationally recognised neutral territory; to develop a global maturity adapted to the future not the past. We can only transform humanity by changing ourselves. ${ }^{8}$

Raël-bevægelsen er på ingen måde enerådende. Der findes en lang række UFO-kulter, som på tilsvarende vis hævder at repræsentere et ikke-jordisk rumfolk, hvis betydning for menneskeheden er absolut. De fleste er små, som det er tilfældet med næsten alle nye religioner, men enkelte, som f.eks. The Aetherius Society med base i London, er store og velorganiserede. ${ }^{9}$ Raël-bevægelsens særpræg er imidlertid den intime tilknytning til de store monoteistiske religioner, hovedsagelig jødedommen. I langt de fleste tilfælde er UFO-kulterne forbundet med teosofiske (og dermed hinduistiske og buddhistiske) forestillinger, og som sådan integrerede elementer i New Age-bevægelsen.

Da New Age-filosofierne med få undtagelser distancerer sig fra jødedommen, der klassificeres som den gamle menneskeheds religion, er dette en afgørende forskel. ${ }^{10}$ En af fortidens førende teosoffer, Alice 


\section{Mikael Rothstein}

Bailey (1880-1949), som stadig er autoritativ i New Age-sammenhæng, har udtrykt det således: Problemet med jøden er, at han er tilfreds med en 5000 ar gammel religion, og ingen tegn viser på forandring. ${ }^{11}$ Den religiøse beskæftigelse med UFO'er og extraterrestriale væsner er et udpræget - og stadig stærkere manifesteret - New Age-fænomen, men på tværs af New Age-bevægelsens manglende veneration for jødedommen har Claude Vorlihon (Raël) altså formuleret en UFO-teologi med jødiskkristen rod.

Raël-bevægelsens lære kan ganske vist ikke kaldes en teologi i teknisk forstand. Trossystemet er ikke en »lære om Gud«, eftersom Gud ikke anerkendes i den klassiske betydning. Trossystemet er først og fremmest en ætiologi, hvis fokus er sat på menneskets og dermed livets opståen. Basis i denne ætiologi er rumvæsnerne - Elohim - hvis genetiske manipulation erstatter den jødisk-kristne guds skabelse ved ordet. Men samtidig indskrives Elohim reelt i den jødisk-kristne åbenbaringstradition og finder deres plads $\mathrm{i}$ den jødisk-kristne tidsopfattelse. Det er ikke længere Gud, der viser sig i historien og handler med eller for sine udvalgte. I Raëls lære er det Elohim, der manifesterer sig gennem hele åbenbaringshistorien, og $\mathrm{i}$ en vekselvirken med menneskene søger at gennemføre det, der skal til, før en genfødt og frelst menneskehed kan se dagens lys (jf. som allerede citeret ovenfor: It was they who sent all the PROPHETS such as Moses, Jesus and Mohammed to progressively educate humanity with a message adapted to the level of understanding of each age).

Raël betegnes som regel profet, han synonymiseres med Moses og Jesus, og i enkelte sammenhænge betegnes han ligefrem som Messias. For hans tilhængere er der ingen som helst tvivl: Han er forløseren, frelseren. ${ }^{12}$ I forbindelse med en færd (i en flyvende tallerken) til Elohims hjemplanet, erfarede han, at han i virkeligheden var søn af Elohims leder Jahve (se nedenfor). Som sådan var han derfor halvbror til Jesus, som angiveligt var resultatet af en kødelig forbindelse mellem en jordisk kvinde (Maria) og Jahve ombord i en flyvende tallerken. ${ }^{13}$ Raël-bevægelsens selvforståelse som det endelige redskab i Elohims plan for livet på jorden er således $\mathrm{i}$ fuld harmoni med den traditionelle jødiskkristne forestilling om, at Gud med Messias intervenerer endeligt for 


\section{Da Gud blev til en lille grøn mand}

definitivt at stadfæste sit theokrati på jorden. Strukturen er bibeholdt, men den transcendente Gud er erstattet af humanoider, hvis teknologiske kapacitet har været forudsætningen for livet på jorden. ${ }^{14}$ Idet fortidens profeter forklares som Elohims repræsentanter, tager man på den måde den jødisk-kristne åbenbaringshistorie til indtægt for egne synspunkter. I et personligt brev fra The British Raëlian Movements sekretær Erik Wortelboer hedder det bl.a.:

No matter what they say, it is a fact that the Elohim are behind the whole thing. How would you otherwise explain the descriptions of flying saucers in the Bible? You see, it is not a matter of interpretation. It is a question of understanding. ${ }^{15}$

Denne kobling er et skoleeksempel på den brug af eksisterende traditioner, som nye religioner gør, og altid har gjort. Raëls lære er således kohærent og (ud fra sine egne præmisser) logisk. Det er dog bemærkelsesværdigt, at selve skabelsen ikke forklares i Raëls lære. Som en slags appendix til den centrale forkyndelse, hvis centrum er livets opståen på jorden, forklares det, at skabelse ikke kan betragtes som et meningsfyldt begreb. Man taler i stedet om infinity in time and space og siger som følger:

All that exists has always existed and will always exist in form of matter or energy. The matter which composes us has always existed and always will, even after our death. We are made up of material eternity. $\gg$ From dust you came and to dust shall you return «. This concept is called infinity in time and space (...) The Elohim have explained that our concept of an immaterial God is incorrect and that there is no soul which flies out of the body after death. ${ }^{16}$

Hvor andre nye religioner med naturvidenskabelig empati begejstres for den dynamiske »Big bang«-teori, som forklarer universet som udfoldet fra et bestemt punkt, repræsenterer Raël-bevægelsen det modsatte, hvilket i sig selv er bemærkelsesværdigt. Hvis Raëls lære skal forbindes til et naturvidenskabeligt teoretisk system bliver det snarere den såkaldte »Steady-state«-teori, som netop går ud fra, at universet ikke er skabt, men at det altid har været der. ${ }^{17}$ Ingen steder i bevægelsens materiale har jeg imidlertid fundet referencer til denne teoridannelse, hvilket er besynderligt, når man betænker Raëls interesse for naturvidenskabelig 
identifikation og legitimering.

Ud fra en religionsvidenskabelig betragtning er det interessante i denne sammenhæng, at man ingen egentlig kosmogoni har. Selve skabelsen anses for givet, og al opmærksomhed koncentreres om menneskets opståen. ${ }^{18}$ Raël-bevægelsens antropologi kiler sig således ind som det altafgørende. Hvor alverdens religioner traditionelt repræsenterer forestillinger om en dynamisk, progressiv udfoldelse af verden, taler Raël kun om livets evolution (dvs. intelligent styrede og planlagte udvikling). I den sammenhæng præsterer man fortolkninger af Det gamle Testamentes skabelsesmyter, som demonterer netop det kosmogoniske aspekt. Overordnet, forklarer Raël, er der tale om fejllæsninger og misforståelser. Teksten er et vidnesbyrd om Elohims genetiske eksperimenter, ikke om universets skabelse eller en transcendent gud.

Denne reinterpretation kan følges bid for bid i Raëls produktion og forbindes til centrale pasager i 1. Mosebog. Elohim hævdes at have forklaret Raël, at jorden, da de oprindelig ankom hertil for 22.000 år siden, var fyldt med vand, og hyllet $\mathrm{i}$ en tyk tåge (1. Mosebog 1, 2). Elohim hævede materiale fra havets bund og etablerede landmasser (1. Mosebog 1,9). ${ }^{19}$ Herefter udviklede de forskelige planter i deres laboratorier (1. Mosebog 1, 11), hvorefter maritime dyr og sidenhen fugle blev sluppet løs, til sidst efterfulgt af landdyrene (1. Mosebog 1, 20-24). Muligvis, forklarer Raël, havde Elohim medbragt enkelte af arterne, som således ikke blev konstrueret på jorden. Endelig udviklede Elohim mennesket på en måde, så det lignede dem selv (1. Mosebog 1, 26). Tilsyneladende har Elohim ved den lejlighed dannet forskellige racer eller folkeslag. I hvert fald, forklarer Raël, udpegede Elohim jøderne til at være dem, som efter alt at dømme ville få størst succes, angiveligt fordi de var særligt intelligente. ${ }^{20}$ Med henvisning til en i ufologernes kredse meget omdiskuteret passus i 1 . Mosebog $(6,4)$ - den, hvor der tales om »gudesønnerne«, der tog menneskedøtrene til ægte - hævder Raël, at jøderne netop nedstammer fra de børn (Nephilim), som blev resultatet af denne forbindelse.

Den mytologiske reinterpretation slutter imidlertid ikke med det. På Elohims hjemplanet, forklarer Raël, regerer Jahve, som altså ikke er en guddom, men blot den politiske leder. Af frygt for de jordiske menne- 


\section{Da Gud blev til en lille grøn mand}

skers fremtidige mulighed for at true universet blokerede denne Jahve for kommunikation til jorden allerede umiddelbart efter livets implantering. Han mente, at jordens mennesker om nødvendigt måtte tilintetgøres, men her sagde Elohim, hans undersåtter, stop. I opposition til Jahve besluttede man at afsløre livets mysterium og de kosmiske sammenhænge for menneskene, hvilket således skete med "gudesønnernes« intervention anført af den ledende Elohim ved navn Lucifer. Inden da havde Jahve allerede bestemt, at Lucifer og hans kolleger skulle eksileres på jorden, men i lyset af begivenhederne bestemte han, at jorden skulle udslettes. Herefter præsenteres vi for endnu en mytologisk innovation, om end strukturen fra det originale forlæg er intakt. Med Raëls egne ord:

However, the exiled creators, informed of the project [dvs. jordens ødelæggelse med atomvåben afsendt fra Jahves hjemplanet], asked Noah to build a spaceship which would orbit the earth during the cataclysm. ${ }^{21}$

På den måde overlevede livets byggestene i Noahs gigantiske rumskib, skønt ikke alle arter blev udsat igen efter katastrofen. Dinosaurerne blev f.eks. ikke reetableret på jorden, forklarer man. Da livet skulle reimplanteres på planeten, indså man, at visse arter var uhensigtsmæssige for den økologiske balance, hvorefter de ikke blev klonet på ny. ${ }^{22}$

Denne mytologiske beretning kan under ingen forhold bringes på formel med sit jødisk-kristne forlæg. Imidlertid er der op gennem middelalderen flere eksempler på, at Lucifer opfattes som skaberen af den materielle verden (blandt katharer og bogomiler f.eks.), en tanke, hvis rødder kan spores tilbage til gnostiske forestillinger. ${ }^{23}$ Der er også en tradition for en positiv tolkning af Lucifer i nutidens okkulte miljøer, også blandt folk, der ikke forstår sig selv som satanister. ${ }^{24}$ Inversionen af det bibelske forhold mellem Jahve og Lucifer i Raëls lære har således sit forbillede i de subkulturelle religiøse miljøer, som en moderne UFO-kult må siges at ligge i forlængelse af.

På den måde indtager de ikke-jordiske humanoider en prominent plads i mytologien. I forhold til den almindelige synonymisering mellem "ufonauter « og folketroens nisser og alfer, er dette et ikke uvæsentligt avancement. Hvor folkloristerne typisk vil se UFO'ernes besætningsmed- 
lemmer i sammenhæng med det før-kristne Europas guder, som med tiden blev dæmoniserede og henvist til underverdenen, har Raëls Elohim rejst sig til den højeste sfære. De to synkretiserende lag er således den europæiske folketro på den ene side og den jødisk-kristne mytologi på den anden. Hvor alferne og nisserne tidligere beboede de liminale, kaotiske sfærer (typisk den mørke skov), kommer humanoiderne i dag fra det mørke og ukendte rum, men med koblingen til den dominerende, "store « religiøse tradition er deres funktion blevet en anden.

En række af de mangfoldige andre eksempler på religio-mytologisk kreativitet i Raël-bevægelsen, som eksemplificerer religionens dynamik og foranderlighed, skal tages op i det følgende.

\section{Millenarisme}

Som de fleste andre religiøse sekter, nu som i fortiden, har Raël-bevægelsen et udpræget millenaristisk præg. Vi hævdes at leve i den sidste fase af "Det Store $\AA$ r «, hvis begyndelse falder sammen med Elohims første indsats på jorden for 22.000 år siden. Da mennesket $\mathrm{i}$ midten af 1940'erne havde udviklet atomvåben, tog Elohim det som et tegn på, at vi nu enten ville ødelægge os selv, eller stå på tærsklen til et teknologisk baseret paradis - eller rettere et post-teknologisk paradis, eftersom teknologien vil finde en plads, hvor den eksklusivt bliver til gavn og glæde (ingen forurening, ingen støj etc.). ${ }^{25}$ Ifølge Raël ser det ud til, at vi klarer udfordringen. Han mener, at ... humanity is able to control the atom, and able to act accordingly. The nuclear weapons have forced Man to think deeper than ever before. And we have! ${ }^{26}$ Raëls millenaristiske forestillinger harmonerer udemærket med New Age-bevægelsens forestilling om Vandmandens Tidsalder (»Age of Aquarius«), som i disse år for alvor menes at sætte sig igennem. Det er imidlertid med jødiske referencer, Raël forklarer sig. Afslutningen af de 22.000 år falder således sammen med det jødiske folks tilbagevenden til Det hellige Land i 1946-48, hvilket - forklarer han - er et bevis for nutidens messianske kvalitet. Her er parallellen til andre, mere konventionelle religiøse forestillinger tydelig. Det er således helt gennemgående, at jødiske såvel som kristne religiøse zionister har set oprettelsen af staten Israel som en forudsætning for den altomfattende realisering af den messianske tid. 


\section{Da Gud blev til en lille grøn mand}

For Raël består næste fase $\mathrm{i}$ forberedelserne til den messianske tid (dvs. Elohims komme) i en bevidstgørelse om Elohims realitet. Idet man også tager kristne synspunkter til indtægt, er spørgsmålet, hvor lang tid man har på sig. Lukas $(21,29-33)$ lader Jesus tale om tegnene på gudsrigets komme. Varslet lyder bl.a.: Denne sloegt skal ikke forgå, før det er sket alt sammen. I lighed med kristne fundamentalister (som også betragter jødernes tilbagevenden til Det hellige Land som et varsel om gudsrigets komme) må Raël-bevægelsen overveje, hvornår »en slægt er forgået«. I dag er det ca. 45 år siden Israel blev oprettet, og knap 90 år siden den første jødiske indvandring så småt begyndte. Det er med andre ord netop nu, i disse år, at tingene for alvor vil ske. Et medlem af Raëlbevægelsen forklarer: It is now! Right now! All we need - not only us the Raëlians, but all mankind - is the Embassy. ${ }^{27}$

Som angivet ovenfor ønsker man at etablere en ambassade for Elohim på neutral grund. Denne ambassade, hvor Elohim tænkes at lande under fuld international mediedækning, er den endelige forudsætning for fuldbyrdelsen af Elohims vilje, og altså Raël-bevægelsens mål. Elohim har selv udpeget stedet. Ambassaden skal ligge »nær Jerusalem«. Parallellen til jødiske og kristne gruppers forestilling om Det tredie Tempel som forudsætningen for Messias' komme eller gudsrigets indstiftelse er oplagt, og faktisk er templet en hjørnesten i bevægelsens agitation. I et brev til religiøse såvel som verdslige ledere i Israel, hvori bevægelsen redegør for sine intentioner, hedder det bl.a.:

We all know that the existence of The State of Israel can be justified only as a place to welcome the Elohim in the Third Temple; that is to say, the Embassy Of The Elohim who are the Extra-terrestrials who created humanity in their laboratories in Jerusalem. ${ }^{28}$

Raël vil dog ikke, som visse fundamentalistiske kristne, destruere Klippemoskeen på tempelbjerget. I sagens natur har han heller ingen forventning om, at Gud vil ødelægge moskeen. Raëls ambassade tænkes at føje sig smukt ind $\mathrm{i}$ den lokale arkitektur, selv om bevægelsens æstetik ikke just minder om den lokale stil. ${ }^{29}$ 


\section{Forfædrekult og selvforståelse}

Der er flere grunde til at karakterisere Raël-bevægelsens dyrkelse af Elohim som et udtryk for forfædrekult. Elohim er menneskelige væsner: »Our Fathers from Space«. Mennesket er forpligtet til at forholde sig respektfuldt og underdanigt over for dem, ikke fordi de ønsker underkastelse, men fordi de er bærere af menneskehedens intellektuelle såvel som genetiske ressourcer. Mennesket skal lade sig vejlede af dem og respektere dem på en måde, der ligner den, vi kender fra kulturer, hvor genealogiske strukturer og aldersklassesystemer er bestemmende for samfundets hierarki. Betoningen af menneskets herkomst og nedstamning indtager endvidere en plads, der er mindst lige så central som den jødiske idé om Israels folk. Raël-bevægelsens selvforståelse som en udvalgt skare (we are here for the benefit of all mankind, chosen for this very special mission), ${ }^{30}$ er f.eks. tydelig. Med tanke på Raëls delvis jødiske baggrund, og hans identifikation af jøderne som Elohims »masterpiece«, er der grund til at tro, at jødedommens stærke historiebevidsthed og guddommelige udvælgelse og forpligtelse søges overført til Raël-bevægelsen: Today everybody has the right to be chosen. Join us and see for yourself! ${ }^{31}$

Raël forklarer yderligere, at relationen mellem det jordiske menneske og Elohim blot er et led i en uendelig kæde af tilsvarende relationer. Elohim er selv blevet skabt af en af dem overlegen race, som igen er produktet af en tredie races eksperimenter etc.: [The Elohim] were created by other people coming from another planet, who had been created by other people coming from another planet, and so on to Infinity. ${ }^{32} \mathrm{Men}-$ nesket på jorden står netop nu over for at opfylde det, som Raël anser for målet med livet: At skabe nyt liv og kolonisere universet yderligere. Det mest spektakulære element i Raël-bevægelsens kosmologi knytter sig til denne forestilling. Universet er, forklarer man, beboet af intelligent liv på alle niveauer. Der eksisterer verdener i de mindste støvkorn såvel som inden i os, verdener så små, at deres beboere ikke er i stand til at begribe vores eksistens. Tilsvarende er vores univers selv et atom $\mathrm{i}$ en endnu større enhed, som igen indgår i en endnu større. Raëls billedlige tale om, at disse verdener udgør et universelt kosmisk væsen har fællestræk med kabbalistiske (og dermed jødiske) forestillinger om »Den 


\section{Da Gud blev til en lille grøn mand}

gamle af dage« (også betegnet Macroposopus). Raël betoner yderligere, at vi har særlige forpligtelser over for de extraterrestriale væsner, der besøger os, men som ikke er Elohim. Disse andre væsner anses nemlig også for at være Elohims værk, og det er op til os at vække deres forståelse herfor. ${ }^{33}$

\section{Raël-bevægelsen og Jehovas Vidner}

Raëls lære forekommer ved første øjekast ny og mærkelig. Det skal derfor fremhæves, at andre trossamfund har foretaget omskrivninger af det samme stof på en måde, der i høj grad minder om det, Raël har præsteret. Det gælder f.eks. Jehovas Vidner, som er en forkætret sekt, hvis lære betragtes med største foragt blandt main-stream kristne, og som er et klassisk eksempel på en sekt, som har fundet en egen identitet gennem en reinterpretation af religionens myter og dogmer. Raël-bevægelsen er således hverken den eneste, den første eller den sidste, der er gået eller vil gå ad den vej. For at påvise dette har jeg kort beskrevet de påfaldende sammenfald, der er mellem de to religioners trossystemer. Det kan næppe dokumenteres, men det er sandsynligt, at de samme subkulturelle og »uautoriserede« religiøse ideer har påvirket menings- og betydningsdannelsen i begge religioner.

Det er velkendt, at Jehovas Vidners kristendomsforståelse ikke kan accepteres af (andre) kristne, og det kan heller ikke undre, at Raël-bevægelsen står isoleret $\mathrm{i}$ forhold til jødiske såvel som kristne grupper. ${ }^{34}$ Til gengæld er det bemærkelsesværdigt, at der forekommer en række sammenfald mellem Jehovas Vidners og Raëls lære. Begge religioner regner (som så mange andre) med, at 144.000 udvalgte skal leve evigt. Jehovas Vidner lærer, at en del allerede er udvalgt (de står af og til frem og meddeler deres trosfæller, at de er blevet udvalgt), mens Raël lærer, at ca. 8.400 afdøde jordmennesker allerede er blevet genskabt ved kloning, og at de takket være "evig kloning « vil leve evigt på Planet of the Eternals, hvortil de er blevet bragt. Med henvisning til Johannesapokalypsens tale om Bogen med de Syv Segl betragter Jehovas Vidner det sjette segl (Apokalypsen 6,12) som en dommedagstrussel. Raël tager teksten til indtægt for opdagelsen og udnyttelsen af atomvåben. Det syvende segl er så selve dommedag, i Raëls interpretation en atom-kata- 
strofe, hvilket harmonerer med hans forestilling om, at det netop var udviklingen af atom-bomben, der fik Elohim ud af busken.

Elohim har meddelt Raël, at en udvalgt skare vil få lov til at overleve katastrofen:

The people who will be sealed in the forehead will be those who will have their cellular plan transmitted by manual contact between our prophet and their frontal bone, which contains the purest and the exact genetic code. ${ }^{35}$

Dette segl tages særdeles bogstaveligt. Raël-bevægelsens kernemedlemmer har udfærdiget testamentariske erklæringer, hvori de stadfæster, at deres pandebrask skal fjernes fra liget og (via organisationen) transporteres til Elohim. På den måde vil de kunne sikre sig, at Elohim har det bedst egnede genetiske materiale, når liget skal rekonstrueres (klones) til live. ${ }^{36}$ Seglet på panden og antallet af udvalgte relaterer sig naturligvis til Johannesapokalypsen (7, 1-8 og 14, 1.3-5), hvori det profeteres, at de udvalgte skal bære Den levende Guds Segl på deres pander og regere verden med ham på Zions bjerg. Hvor f.eks. Jehovas Vidner tager apokalypsens ord for pålydende, giver Raël dem en drejning, uden dog at gøre dem hverken allegoriske eller symbolske. Zion er erstattet med Elohims hjemplanet, Planet of the Eternals, hvor de udvalgte i genskabt form vil dvæle - ikke med den levende Gud, men i selskab med Elohim, Jahve - deres leder - og de tidligere profeter. I enighed med Jehovas Vidner lærer Raël-bevægelsen, at de som ikke udvælges vil forgå. Der er ingen evige pinsler $i$ helvede, og ingen forestillinger om en af kroppen uafhængig sjæl. Argumentationen herfor ligner til forveksling den, der er så karakteristisk for Jehovas Vidner: Læren om en sjæl er ikke oprindelig kristen, men skyldes indflydelse fra neoplatonistiske og ægyptiske forestillinger. ${ }^{37}$ I forlængelse heraf - og i fuld harmoni med fornægtelsen af en guddom - anerkender Raël-bevægelsen ikke eksistensen af åndelige væsner uden krop. ${ }^{38}$

\section{Konklusion}

De universelle religiøse mønstre er tydelige overalt i Raëls forkyndelse. Fra første færd, hvor de overmenneskelige væsner manifesterer sig på et bjerg, til den apokalyptiske finale, hvor de udvalgte skal indgå i en para- 


\section{Da Gud blev til en lille grøn mand}

disisk tilstand, ser man strukturer og forløb, som er typiske - tør man sige arketypiske? - for menneskenes religioner. Mødet med den mandala-formede flyvende tallerken og dens besætning har karakter af epifani, Raëls rejse til Elohims ideelle hjemplanet har paralleller til Elias' rejse i ildvognen, Jesu opstandelse, Muhammeds himmelfart og shamanistiske rejser, konstruktionen af Elohims ambassade kan identificeres som konstruktionen af et kosmisk centrum, den "sensuelle meditation « (se note 38) kan sammenlignes med healings- og renselsesriter og så videre. ${ }^{39}$

Selv om de ætiologiske elementer fremhæves, er de soteriologiske implikationer nok så vigtige. Vi står over for en materialistisk indstillet religion (med Raëls egne ord en ateistisk religion), hvis verdensbillede $\mathrm{i}$ hovedsagen består i en (pseudo)videnskabeliggørelse af jødisk-kristen mytologi. Der er ikke længere tale om nogen dualistisk funderet drøm om sjælens frelse. Det soteriologiske perspektiv omskrives til at vedrøre evigt fysisk liv på en anden planet. I den forstand bryder man på de afgørende punkter med det mytologiske fundament, man udgår fra, men på den anden side kan forestillingen om fysisk udødelighed også tolkes som en fuldstændigg ørelse af det kristne løfte om, at døden er besejret ved Kristi opstandelse, og som en konsolidering af gamle jødiske forestillinger om kødets opstandelse. For Raël er døden besejret takket være kloning »ad infinitum«. Fysisk regenerering - opstandelse - vil være mulig på grundlag af en eneste celle, forklares det. Hele dette spektrum er indeholdt $i$ en eskatologisk forestilling om et atom-helvede, hvis afværgen alene kan sikres ved menneskehedens besindelse. Trossystemets to komponenter peger således i hver sin retning: Bagud via den traditionelle mytologi og fremad via udsigterne til en perfektioneret videnskab og teknologi.

I en analyse af Scientology, som på alle måder søger at videnskabeliggøre religionen, bl.a. ved at introducere teknologi som en værdi i sig selv, har religionssociologen William Bainbridge teoretiseret over denne religions fremtidsudsigter:

Among Scientologys strengths are its several links to science and technology and thus to the crucial cultural forces of our century. Born in science fiction, it can draw on this storehouse of novel ideas and on the vast popularity that this literature has recently achieved. While the new cosmological ideas of world ensemble 
and anthropic principle have as yet achieved little popularity, they provide a profound basis for development of Scientological doctrines that would make them highly respectable and attractive to intellectual elites.

While it is impossible to predict the fate of Scientology as a particular religious organization, we must suspect that some religion very much like Scientology will be a major force in the future of our civilization. ${ }^{40}$

Raël-bevægelsen beskriver en ekstrem videreførelse af jødisk-kristen tradition i tilstræbt harmoni med de vildeste visioner, som nutidens teknologiforblændelse kan præstere. Hertil kommer, at det klassiske religi$\emptyset$ se forlæg ufortrødent er i centrum - alle omskrivninger til trods. I modsætning til Scientology - som også har rumrejser, liv i fjerne galakser og mere til på programmet - har Raël-bevægelsen dermed to støttepiller, og tager vi arven fra folketraditionen i betragtning, hele tre. Tør man forestille sig en stabil og velkonsolideret religion på lidt længere sigt? Forfejlede profetier behøver ikke slå en religion ud, og længslen efter et mål, som synes evigt fjernt, kan virke ansporende snarere end demoraliserende. ${ }^{41}$ Ud fra en umiddelbar betragtning er der ingen grund til at tro, at Raël og hans religion vil kunne få jødedommen og kristendommen i tale. Det må helt enkelt anses for udelukket. F.eks. vil »ambassaden« i Jerusalem formodentlig aldrig blive realiseret. Men religionen behøver ikke omgivelsernes anerkendelse for at overleve. Raël-bevægelsen præsenterer sin messias med stor selvsikkerhed, og de troende føler, så vidt jeg kan vurdere, en stærk entusiasme. UFO-kulterne har eksisteret siden begyndelsen af 1950'erne under indtryk af den teknologiske udvikling og efterkrigstidens behov for nye værdier. Med Raël-bevægelsen ser vi et foreløbigt klimaks, hvis levedygtighed endnu ikke er bevist, men hvis chancer - alting til trods - er gode. Sekter skal ikke nødvendigvis være store for at kunne overleve.

Religionshistorikeren, der i forvejen er vant til lidt af hvert, må i disse år erkende, at der ingen grænser er for, hvad man må forvente. 


\section{Da Gud blev til en lille grøn mand}

\section{Noter}

1. Se f.eks. Robert S. Ellwood og Harry B. Partin, Religious and Spiritual Groups in Modern America, Second edition, Prentice Hall (New Jersey) 1988, s. 111-133.

2. Claude Vorlihon (Raël), The Message Given to Me by Extraterrestrials: They Took Me to Their Planet, Tokyo 1989 (opr. 1986) (cit. Vorlihon 1989a).

3. Et mere realistisk bud på antallet af medlemmer ses af den størrelse, skaren af fremmødte havde, da Raël besøgte Canada, som er en af bevægelsens baser: 300 personer deltog i arrangementerne ifølge bevægelsen selv (Apocalypse International. Bulletin de liaison du mouvement raëlien intemational, no. 75, 1991)

4. Standard følgebrev fra British Raëlian Movement, BCM Minstrel, London WC1N 3XX. Brevet er fra april 1992 (år 46 efter bevægelsens tidsregning, som er det der angives (jf. note 25)).

5. Raël-bevægelsen ligger her $i$ forlængelse af den legendariske Erich von Däniken, hvis teorier om, at jorden er blevet besøgt af rumfolk siden tidernes morgen, og at disse bes $\emptyset \mathrm{g}$ kan udledes af alverdens helligtekster og symboler, siden begyndelsen af 1970'erne har været ideologisk skyts for UFO-entusiaster (se f.eks. Erich von Däniken, In Search of Ancient Gods: My Pictorial Evidence for the Impossible, New York 1975).

6. De almindeligt tilgængelige opslagsværker angiver blot, at Elohim oprindelig betød »guder«, men at betegnelsen med tiden (dvs. efter eksilet) bliver eksklusiv for Gud (Jahve)

7. Are You Ready to Meet An Extra Terrestrial? They Need An Official Embassy. Folder fra British Raëlian Movement. (Ingen data. Formodentlig fra 1989 eller 1990).

8. Sammesteds.

9. Roy Wallis, "The Aetherius Society: A Case Study in the Formation of a Mystagogic Congregation «, i Roy Wallis (ed.), Sectarianism: Analyses of Religous and Non-Religious Sects, London 1975, 17-34.

10. Mikael Rothstein, »Jødedom og New Age«, Religion - Tidsskrift for Religionslcererforeningen for Gymnasier og $H F$ nr. 2, 1992, s. 20-29.

11. Alice Bailey, Kristi tilsynekomst, København 1976 (opr. 1948)

12. Raëls status som Messias kan enten forstås som den endelige opfyldelse af de jødiske messiasforventninger, eller mere oplagt som en udnyttelse af den kristne forventning om Kristi genkomst. Dette eksempel illustrerer smukt, hvordan Raëls lære vedvarende medierer mellem jødiske og kristne forudsætninger.

13. Vorilhon $1989 \mathrm{a}, 113 \mathrm{f}$.

14. At Raël-bevægelsen ingen egentlig teologi kan præstere, betyder naturligvis ikke, at der ikke er tale om religion. Mange religionsdefinitioner opererer således med »overmenneskelige væsner« (som Elohim) som kriterium (se f.eks. Melford Spiro, "Problems of Definition and Explanation«, i M. Banton, Anthropological Approaches 


\section{Mikael Rothstein}

to the Study of Religion, London 1966, 96), mens andre, hvis fokus i højere grad er funktionalistisk, næppe behøver guder eller overmenneskelige væsner overhovedet.

15. Brev til forfatteren af 27. april 1992. Der tænkes bl.a. på Ezekiels bog, hvor profeten angiveligt konfronteres med menneskelignende skikkelser og besynderlige fartøjer (Ezekiel 1, 1-28).

16. Fra det informationsmateriale, som bevægelsen fremsender ved henvendelser (Ingen data. Modtaget maj 1992).

17. Encyclopedia Britannica vol. 17, Chicago 1992, 787-794.

18. Dette perspektiv er karakteristisk for en del skriftløse kulturer, hvis fysiske miljø tages for givet. Det er i højere grad de levende væsners og de sociale institutioners oprindelse, der fokuseres på i myterne.

19. Det velkendte kosmogoniske dykker-tema er genkendeligt her.

20. Claude Vorlihon (Raël), Let's Welcome Our Fathers from Space: They Created Humanity in Their Laboratories, Tokyo 1989 (opr. 1986), 24 (cit. Vorlihon 1989b).

21. Vorilhon $1989 \mathrm{~b}, 25 \mathrm{f}$.

22. Vorlihon 1989a, 172.

23. Jeffrey Burton Russell, Witchcraft in the Middle Ages, Ithaca 1972, 120 m.fl.st.

24. Hele sondringen mellem Lucifer og Satan, som trives i okkulte sammenhænge, hvor Lucifer identificeres med Venus, mens Satan forbindes til Mars, kan jeg ikke komme ind på her, men forholdet har givetvis betydning for Raëls formulering af sin mytologi. Den myte, hvori Prometheus søger at beskytte sin skabelse mod Jupiter, er en nærliggende parallel fra en anden del af den europæiske religiøse bevidstheds fundament.

25. Raël-bevægelsens tidsregning starter i 1945 og har atombomben over Hiroshima som sit udgangspunkt.

26. Raël, Messenger of the Age of Science. Folder fra British Raëlian Movement (Ingen data. Formodentlig fra 1989 eller 1990).

27. Brev til forfatteren af 19. marts 1992, der er et svar på det direkte spørgsmål: "Hvornår regner I med, at Elohim vælger at vise sig?«

28. Gengivelse af brev, stilet til Israels religiøse og politiske ledere. Brevet er bl.a. underskrevet af Leon Mellul, som er »responsible for the Jewish Communities« (Apocalypse International - Review of International Raëlian Movement nr. 84, 3).

29. I et af bevægelsens organer, Apocalypse International - Review of International Raëlian Movement nr. 84, 14 f., er der farvebilleder af den model, som man baserer sin agitation på. Konstruktionen består af bobler og kupler, som på alle måder er i harmoni med den moderne science fictions billede af rumalderens funktionalisme. Billedet kan erhverves som plakat, postkort $\mathrm{mm}$.

30. Sammesteds.

31. Raëlian ideas (uden år. Engelsksproget pamflet fra ca. 1990), s. 2.

32. Vorlihon $1989 \mathrm{~b}, 56$.

33. Sammesteds 13 . 


\section{Da Gud blev till en lille grøn mand}

34. End ikke Jews for Jesus - en jødisk sekt, hvis mål det bl.a. er at genopbygge templet og genindstifte ofringerne - vil høre tale om Raël og hans ambassade. Som svar på spørgsmålet, om Jews for Jesus (i England) kender til Raëls plan, modtog jeg følgende oplysning: We have once recieved a letter from this group. It was read and returned with this message: Do never ever contact us again! Jesus is the Messiah of the Jews, not this Raël. This may answer your question (Brev til forfatteren af 2. marts 1992). Se i øvrigt Mikael Rothstein, Er Messias en Vandmand? - En bog om messiaskult og New Age, Gjellerup/GAD, København 1993 (under udgivelse). - Mig bekendt er Raël-bevægelsen også isoleret fra langt de fleste New Age-grupper.

35. Vorilhon $1989 \mathrm{a}, 125 \mathrm{f}$.

36. Bevægelsen har særlige retningslinier i de tilfælde, hvor myndighederne nægter at udlevere pandeskallen. Eftersom religionen er ung, og eftersom den efter alt at dømme rekrutterer blandt yngre mennesker (oplyst af Raël-bevægelsen i England), så er erfaringen med disse problemer givetvis begrænsede.

37. Argumentationen findes mange steder i Jehovas Vidners publikationer, f.eks. $\mathrm{i} \gg \mathrm{Er}$ de døde levende? «, Vagttåmet nr. 1, august 1986, 4-7.

38. Her, hvor jeg har koncentreret mig om trosforestillingerne og deres forbindelse til jødisk-kristen mytologi, har der ikke været mulighed for en nærmere beskæftigelse med ritualer, religiøs ikonografi etc. Dog skal det bemærkes, at der som noget centralt i Raël-bevægelsen praktiseres såkaldt »sensuel meditation«, en rituel praksis, som Raël angiveligt har lært af Elohim: Through Sensual Meditation we can link with the infinity that we are a part of because the techniques enable us to: a) Understand how our minds and body function, b) Question the judeo-christian inhibitions of guilt and the mysticism of Eastern traditions, c) Develop our minds and discover our bodies and d) Deprogramme ourselves by ourselves into what we really wish to be (The Message of the Elohim. (Ingen data. Ca. 1990)).

39. En religionsfænomenologisk undersøgelse af Raël-bevægelsen bliver næste skridt i mit arbejde med denne religion.

40. William Simms Bainbridge, "Science and Religion: The Case of Scientology«, i David G. Bromley and Phillip E. Hammond (eds.), The Future of New Religious Movements, Mercer University Press 1987, 74 f.

41. En klassiker i studiet af UFO-kulter er Leon Festinger et alii, When Prophecy Fails, Minneapolis 1956, som netop beskriver, hvordan en UFO-kult i lang tid holdt sammen trods modgang.

\section{Summary}

The International Raëlian Movement, founded by the French journalist Claude Vorlihon (Raël) in 1974, is one of the best consolidated UFO-cults, now present in more than 40 countries. Its teaching is primarily derived from judeo-christian mythology, although the 


\section{Mikael Rothstein}

interpretation throughout is related to modern scientific and pseudo-scientific notions. Further the cult integrates elements of European folklore, which indeed makes it a syncretistic religion. The article describes the teaching of Raël (said to be the Messiah), and points to the fact, that no new religious ideas or structures are promoted. Rather a well known set of ideas are reinterpreted in the syncretistic process. The structure of traditional religion is maintained, but the actors on the mythological stage are new. God or even whe divine" is not recognized. We are facing an atheistic religion which claims that the technology and science of extraterrestrial beings are responsible for life on Earth. The article attempts to show how this transfer from transcendent God to extraterrestrial humanoid are dealt with within the limits of already existing mythological structures.

\section{Mikael Rothstein}

Kandidatstipendiat, mag. art.

Institut for Religionshistorie

Københavns Universitet 